HPV 77 vaccine and 55\% of unvaccinated controls exposed to rubella in Taiwan excreted virus from the pharynx, though the vaccinated group excreted virus on fewer occasions than the controls and had a much lower clinical attack rate. ${ }^{14}$ There is now also some evidence to suggest that reinfection after naturally acquired infection may be commoner than had hitherto been supposed. 1516

Locally produced antibody, particularly IgA, is now recognized as being important in establishing immunity to those viruses which gain entry through the alimentary and respiratory tracts, and it may well be that natural infection results in better local immunity than that produced by a parenterally administered vaccine. A vaccine produced in human diploid cell cultures (RA 27/3) is as yet the only vaccine capable of inducing immunity when given intranasally, ${ }^{17}$ and it may therefore perhaps provide a better or more persistent level of local antibody than that acquired from parenterally administered vaccines. However, there has been some variation in the incidence of successful immunization by this method, though this may well reflect variation in the dose of virus given. Though simple to administer, particularly to children, this vaccine may not be effective if given to people with concurrent upper respiratory infections, which are so common particularly during winter.

The question whether reinfection during pregnancy may damage the fetus is crucial, but if reinfection does occur virus replication is likely to be confined to the nasopharynx, with serum antibody preventing viraemia and transmission of virus to the fetus. The safety of a vaccine depends on its substrate, the communicability of the virus excreted, the risk to the developing fetus, and side-reactions produced. The primary rabbit kidney in which the recently licensed Cendehill vaccine is prepared has undergone many tests and has been shown to be free of any known extraneous agent, the rabbits being kept in isclation under carefully controlled laboratory conditions. The human fetal diploid cultures in which the RA 27/3 vaccine is prepared have many advantages, but the hypothetical risk of transmitting human genetic material which may contain as yet unidentifiable agents has so far precluded its being licensed. The HPV77 vaccine and its derivatives have the great disadvantage that monkey kidney is all too frequently contaminated with extraneous agents, and this must preclude its administration parenterally.

1 International Symposium on Rubella Vaccines, London, 1968. Symposium series in Immunobiological Standardization, vol. XI, Basle, Karger and Karger, 1969.

2 Proceedings of the International Symposium on Rubella Vaccines, Washington. American fournal of Diseases of Children, 1969, 118, suppl.

3 Dudgeon, J. A., Marshall, W. C., Peckham, C. S., and Hawkins, G. T. British Medical fournal, 1969, 1, 271.

4 Hillary, I. B., et al., British Medical fournal, 1969, 2, 531

${ }_{5}$ Parkman, P. D., Meyer, H. M., and Kirchstein, R. L., New England Fournal of Medicine, 1966, 275, 569.
Parkman, P. D., Meyer, H. M., and

- Huygelen, C., and Peetermans, J., Archiv fvr die gesamte Virusforschung, 967, 21, 357

Plotkin, S. A., Farquhar, J., Katz, M., and Ingalls, T. M., American Fournal of Epidemology, 1967, 86, 469

8 Buynak, E. B., Hilleman, M. R., Weibel, R. E., and Stokes, J., Jr., fournal of the American Medical Association, 1968, 204, 195.

9 Parkman, P. D., and Meyer, H. M., Progress in Medical Virology, 1969, 11, 80.

10 Cooper, L. Z., and Krugman, S., Pediatrics, 1966, 37, 335.

11 Hardy, J. B., McCracken, G. H., Gilkeson, M. K., and Sever, J. L., fournal of the American Medical Association, 1969, 207, 2413.

12 Hilleman, M. R., et al., in International Symposium on Rubella Vaccines, London, 1968, p. 349.

13 Meyer, H. M., Parkman, P. D., and Hopps, H. E., in International Symposium on Rubella Vaccines, London, 1968, p. 277.

14 Detels, R., et al., American fournal of Diseases of Children, 1969, 118, 295. 5 Brody, J. A., et al., Fournal of the American Medical Association, 1965, 191, 619.

16 Horstman, D. M., Pajot, T. G., and Liebhaben, H., American Fournal of Diseases of Children, $1969,118,133$.

17 Plotkin, S. A., Katz, M., Farquhar, J. D., and Ingalls, T. H., Lancet, 1968, 2, 1954.

18 Vaheri, A., et al., American fournal of Diseases of Children, 1969, 118, 243.
Although virus is often excreted from the nasopharynx after administration of all vaccines, extensive trials have consistently failed to show transmission of infection, and therefore the risk of infecting pregnant women in this way is likely to be negligible. This is of considerable importance, since there is no evidence that virus attenuation is associated with a reduction in its teratogenic capacity.

Some investigations are in progress in which virus is given to women due to have therapeutic abortions, the products of conception being later tested virologically. A preliminary report suggests that virus may be transmitted across the placenta to the fetus. ${ }^{18}$ Clearly, therefore, vaccine must not be given if there is the remotest chance of the recipient being pregnant. The Department of Health and Social Security strongly recommends that women of child-bearing age are not vaccinated unless the possibility of pregnancy can be ruled out with reasonable confidence for a period of two months following vaccination. In general, children tolerate the vaccine well, though with occasional but acceptable sideeffects, such as low-grade fever, rash, and lymphadenopathy. However, as in naturally acquired infection, effects may occasionally be more severe in adults, particularly a transient arthralgia or arthritis, though these are rare with the Cendehill vaccine.

The Joint Committee on Vaccination and Immunization has not yet made any general recommendations on vaccination programmes, but there is likely to be some demand from women who want to be protected. It is certainly reasonable to offer this, particularly to those who are seronegative and who are potentially at risk from schoolchildren within their family or at work. Perhaps vaccination might also be offered to seronegative women after childbirth, since these mothers may subsequently be at risk from their offspring if they introduce infection into the household during a subsequent pregnancy. In future it is possible that large-scale vaccination programmes will be phased, being at first directed towards girls leaving school or perhaps those aged 11-13 at the time they receive their B.C.G. vaccine. Finally, when vaccines are more plentiful, the reservoir of infection in younger children of both sexes may be tackled, thus breaking the chain of transmission, with the hope of eventually eradicating the disease altogether. What is important is that a safe and effective vaccine is now generally available, and a start may be made in preventing rubella-caused congenital deformities.

\section{Psychosexual Development}

The part which parents play in the psychosexual development of their children is attracting increasing attention. A. A. Messer in a recent article draws attention to yet another facet of this complex subject. He suggests that the normal restraint on sexual attraction between parents and children-the "incest taboo"'-is less strong in the case of stepchildren, whose psychosexual development may, as a result, be endangered.

Investigations of the relationship between parental behaviour and psychosexual development in children have mainly been concerned with homosexuality, the most common sex-

1 Messer, A. A., Archives of General Psychiatry, 1969, 21, 213.

Freud, S., Totem and Taboo and Other Works. London, Hogarth Press. 1955.

3 West, D. J., International fournal of Social Psychiatry, 1959, 5, 85.

4 O'Connor, P. J., British fournal of Psychiatry, 1964, 110, 381.

5 Bene, E., British fournal of Psychiatry, 1965, 111, 803 and 815.

6 Kenyon, F. E., British fournal of Psychiatry, 1968, 114, 1337.

Roth, M., and Ball, J., in Intersexuality in Vertebrates Including Man, ed. Armstrong, C. N., and Marshall, A. J., p. 395. London, Academic Press. 1964.

8 Parker, N., British fournal of Psychiatry, 1964, 110, 489. 
ual deviation. D. J. West, ${ }^{3}$ from a study of hospital records, found that male homosexual inpatients had recalled significantly more often than did a control group of neurotics an over-intense relationship with their mothers and an unsatisfactory relationship with their fathers, who were often absent from home, inept, or aloof. P. J. O'Connor ${ }^{4}$ has confirmed these findings from a study of homosexuals in the armed Forces. E. Bene, ${ }^{5}$ in a controlled study of male and female homosexuals who were not patients, found in both evidence of a poor relationship with an inadequate father but not of strong attachment to an overprotective or forceful mother. F. E. Kenyon ${ }^{6}$ also studying female homosexuals in the community, found that they recollected poor relationships with both parents significantly more often than did a control group of married mothers

Other forms of sexual deviation have been studied less extensively. M. Roth and J. Ball ${ }^{7}$ have compared the family backgrounds of male transsexualists, male homosexuals, exhibitionists, and neurotics. For homosexuals they confirm West's observations; in transsexualists the pattern of family relationship seen in the homosexuals was found but was even more pronounced. Exhibitionists frequently disliked their mothers but otherwise differed little from the neurotic controls.

Because of their importance these findings have been evaluated with caution. West discusses other explanations which could account for some of the facts. Retrospective falsification of a systematic kind cannot entirely be discounted: a homosexual's or a transsexualist's account of his childhood may be coloured by his abormality. Some of the parental attitudes described may have been induced by the abnormal emotions of the child. The weak, emasculated behaviour of a father may be a muted expression of the genetic determinants of homosexuality in his son. But other observations cannot be accounted for on these lines. For instance, O'Connor found that prolonged absence of a father from home during childhood was much more common in homosexuals than neurotics, and Roth and Ball found the same in male transsexualists.

Though the facts are scanty, and some are open to divergent interpretations, cautious preventive measures are nevertheless justified. It is likely that in some instances an abnormal relationship between husband and wife will prove as intractable as is sexual deviation itself. In others-for example, in one of the cases described by N. Parker ${ }^{8}$ - there is the impression that a little help to a parent might have averted homosexuality in her child. Unfortunately the reservations, without which conclusions are misleading, are often lost in the wider dissemination of information. Thus what is intended to be discrete and tentative action is apt instead to become entrenched and unquestioned policy.

\section{Iron and Oral Contraceptives}

Many metabolic changes have been found in women taking oral contraceptive drugs. These have been reviewed recently ${ }^{1}$ and include abnormalities in fat and carbohydrate metabolism, increases in the level of some plasma coagulation factors, particularly fibrinogen and factors VII and IX, and increased concentrations in the serum of hormones, such as thyroxine, insulin, and growth hormone, and of metals, such as copper and iron. The precise mechanisms by which oral contraceptive agents give rise to these changes are probably complex and remain to be worked out. Some of the changes are similar to those found in the middle and later stages of normal pregnancy.
C.-B. Laurell ${ }^{2}$ found that the iron-binding capacity of serum increased in pregnancy, and a similar increase associated with a rise in the serum-iron concentration as well has been observed in women taking oral contraceptive preparations in which oestrogen is combined with progestogen. ${ }^{3-5}$ In these studies on the changes in serum iron induced by oral contraceptives there were either no changes or a slight increase in the haemoglobin concentration in blood. J. M. Jacobi, L. W. Powell, and T. J. Gaffney ${ }^{6}$ have recently reported a comparative study of serum iron and serum iron-binding capacity in pregnancy and during the administration of combined or sequential oral contraceptives. The pregnant women in their study were taking iron prophylactically. In both groups there was a striking increase in both serum-iron concentration and serum iron-binding capacity. The rise in these values in pregnancy occurred in the second and third trimesters and the values returned to normal during the puerperium.

The iron-binding protein in serum, transferrin, was measured by an immunological method and also by a chemical method; the results of the two showed reasonably close agreement. It is thought likely that the higher concentrations of transferrin were due to increased synthesis or release of this substance, perhaps in the liver, rather than to decreased catabolism or redistribution between intravascular and extravascular spaces. The observations of $M$. Briggs and $M$. Staniford ${ }^{7}$ suggest that the rise of serum iron and serum iron-binding protein in women on combined oral contraceptives is due to the progestogenic rather than the oestrogenic component of the preparation.

The biological significance of prolonged alterations in the levels of serum iron and transferrin is unknown. The level of transferrin characteristically increases in iron-deficiency anaemia, and it might be thought that the increase which occurs in pregnancy is due to the greater demand then for iron. Raised transferrin levels may lead to more efficient absorption of iron from the gut in pregnancy and in irondeficiency states, but there is no obvious reason why oral contraceptive drugs should increase the demand for iron. It is possible that the increased transferrin levels in pregnancy and in women taking oral contraceptives are a result of a more general stimulus, of which one of the consequences is increased synthesis of a number of biologically active proteins, including transferrin.

It would be interesting to know whether the increase in serum-iron concentration which follows treatment with oral contraceptive drugs is due to an increased efficiency of iron absorption or to increased mobilization of iron from tissue stores. Whatever the explanation, the combination of higher levels of serum iron and smaller loss of menstrual blood in women taking oral contraceptives than in those using other forms of contraception might make the development of iron-deficiency anaemia less likely. Furthermore, since repeated pregnancy is a cause of iron-deficiency anaemia, a reduction in the number and frequency of pregnancies might also be expected to reduce the incidence of this disease.

\footnotetext{
Metabolic Effects of Gonadal Hormones and Contraceptive Steroids, ed. H. A. Salhanick, D. M. Kipnis, and R. L. Vande Wiele. New York, Plenum. 1969.

Laurell, C.-B., Acta Physiologica Scandinavica 1947, 14, Suppl.

Burton, J. L., Lancet, 1967, 1, 978.

Mardell. M., Zilva, J. F., Lancet, 1967, 2, 1323

adeh, J. A., Karabus, C. D., and Fielding, J., British Medical foumal, $1967,4,708$

6 Jacobi, J. M., Powell, L. W., and Gaffney, T. J., British fournal of Briggs, M., and Staniford, M., Lancet, 1969, 2, 742.
} 